\title{
Waste Certification Program Plan for Oak Ridge National Laboratory
}

Frank C. Kornegay 
This report has been reproduced directly from the best available copy.

Available to DOE and DOE contractors from the Office of Scientific and Technical

Information, P.O.Box 62, Oak Ridge, TN 37831; prices available from (423) 576-8401, FTS 626-8401.

Available to the public from the National Technical Information Service, U.S. Department

of Commerce, 5285 Port Royal Rd., Springfield, VA 22161

This report was prepared a an account of work sponsored by an agency of the United States Government. Neither the United States Government nor any agency thereof, nor any of their employees, makes any warranty, express or implied, or assumes any legal liability or responsibility for the accuracy, completeness, or usefulness of any information, apparalus, product, or process disclosed, or represents that its use would not infringe privately owned rights. Reference herein to any specific commercial product, process, or service by trade name, trademark, manufaclurer, or otherwise, does not necessarily constitute or imply its endorsement, recommendation, or favoring by the United States Government or any agency thereof. The view and opinions of authors expressed herein do not necessarily state or reflect those of the UnitedStatesGovernment or any agency thereof. 
ORNL/TM-13288

Revision 0

WASTE CERTIFICATION PROGRAM PLAN FOR

OAK RIDGE NATIONAL LABORATORY

Frank C. Kornegay

September 1996

Safety and Health

LOCKHEED MARTIN ENERGY RESEARCH CORPORATION

Oak Ridge, Tennessee

prepared for the

U.S. Department of Energy

under U.S. Government contract DE-AC05-96OR22464 


\section{DISCLAIMER}

Portions of this document may be illegible in electronic image products. Images are produced from the best available original document. 
ORNL/TM-13288

Revision 0

WASTE CERTIFICATION PROGRAM PLAN

FOR

OAK RDGE NATIONAL LABORATORY

September 1996

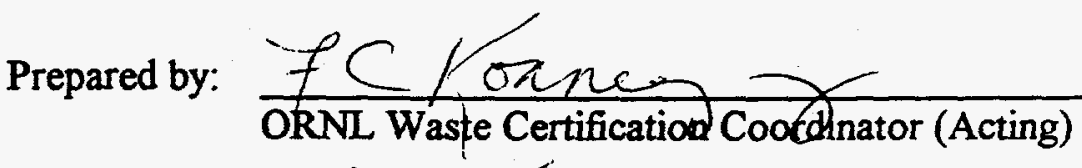

Date: $8 / 21 / 96$

Approved by:

fC

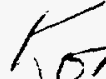

Director, Safety and Health

Date: $8 / 2, / 96$

Concurred by:
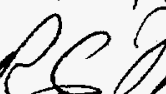

Division Director,

Waste Management and Remedial Action Division 


\section{PURPOSE}

This document defines the waste certification program being developed for implementation at Oak Ridge National Laboratory (ORNL). The document describes the program structure, logic, and methodology for certification of ORNL wastes. The purpose of the waste certification program is to provide assurance that wastes are properly characterized and that the Waste Acceptance Criteria (WAC) for receiving facilities are met. The program meets the waste certification requirements outlined in U. S. Department of Energy (DOE) Order 5820.2A, Radioactive Waste Management, and ensures that 40 CFR documentation requirements for waste characterization are met for mixed (both radioactive and hazardous) and hazardous (including polychlorinated biphenyls) waste. Program activities will be conducted according to ORNL Level I document requirements.

Requirements for managing radioactive and mixed wastes are established in DOE Order 5820.2A. As part of this Order, heads of DOE field organizations are assigned the authority to establish waste management requirements for waste-receiving facilities under their jurisdiction. The development of WACs is one of the requirements specified by the Order for appropriate management of wastes generated by DOE operations. The Order also specifies that each generator of waste shall implement a low-level and mixed waste certification program to provide assurance that the WACs are met. Generators of waste and Waste Management are each responsible for their actions in ensuring compliance with the WAC. In addition, the regulations of the Resource Conservation and Recovery Act and the Toxic Substance Control Act require accurate characterization of wastes such that development of a waste certification program for hazardous and toxic wastes is a responsible management practice.

\section{SCOPE AND LIMITATIONS}

ORNL waste types covered under this program are solid low-level waste (SLLW); transuranic waste (TRU), including TRU mixed and alpha-contaminated waste; liquid low-level waste (LLLW), including all liquid wastes that go to liquid low-level waste, process waste, and nonradiological wastewater treatment facilities; hazardous waste; and mixed waste. These wastes have been incorporated into four ORNL WACs. The four ORNL WACs addressed by this program plan are SLLW WAC, TRU WAC, LLLW WAC, and hazardous/mixed WAC. Wastes not included in the program are sanitary, industrial, storm water, Coal Yard Runoff Treatment Facility Basin influent and effluent, air emissions, and recyclable materials that are not handled by Waste Management prior to off-site transfer. 


\section{PROGRAM DESCRIPTION}

\subsection{PROGRAM ELEMENTS}

In keeping with necessary and sufficient principles, the ORNL Waste Certification Program is designed to meet applicable DOE orders and regulatory requirements through development or use of existing program documents and level 1 procedures in place at ORNL. Figure 1 illustrates the structure of this program. This program has been designed to ensure compliance and provide flexibility so that off-site treatment, storage, and disposal facility (TSDF) options can be included. For example, if off-site treatment and disposal is a viable option, the off-site facility's WAC for that particular waste item or type can be incorporated into the appropriate on-site WAC.

Four WACs will be developed to inform the waste generator of requirements that must be met prior to Waste Management's acceptance of a particular waste type. In addition to specifying the necessary characterization, packaging, labeling, and prohibited items that may or may not be accepted at the TSDF, the WACs also define the basis for those requirements. The process for obtaining WAC variances are described in the individual WACs.

A Waste Generator Implementation Procedure for each WAC will provide specific instructions for how to meet the associated WAC. This procedure will describe, for example, when and how process knowledge can be used to characterize a waste. It will describe the methods by which generators would properly characterize, segregate, package, and label waste. The U.S. Environmental Protection Agency's Data Quality Objectives methodology will be used as appropriate to ensure that the characterization data are appropriate and of necessary and sufficient quality.

The Generator Interface Group (GIG) is an ORNL Waste Certification Program option that is being developed to support the waste generators with their waste characterization and management responsibilities. Various levels of generator interface services ranging from basic service (accepting properly characterized and packaged waste) to full service (providing total support to generators in meeting the WAC requirements) will be available for individual generators or generator groups. The level of service will be determined on a case-by-case basis with the generating organization.

The support level and the associated cost of generator interface will be outlined in a Memorandum of Understanding between individual generators or generating organizations and Waste Management. Generator interface personnel will be assigned to generators on the basis of the level of support desired and the types of waste they generate. Generator interface personnel will be available to provide a wide variety of services to the generator, including completing waste profile descriptions, assisting with characterization and process knowledge requirements, 


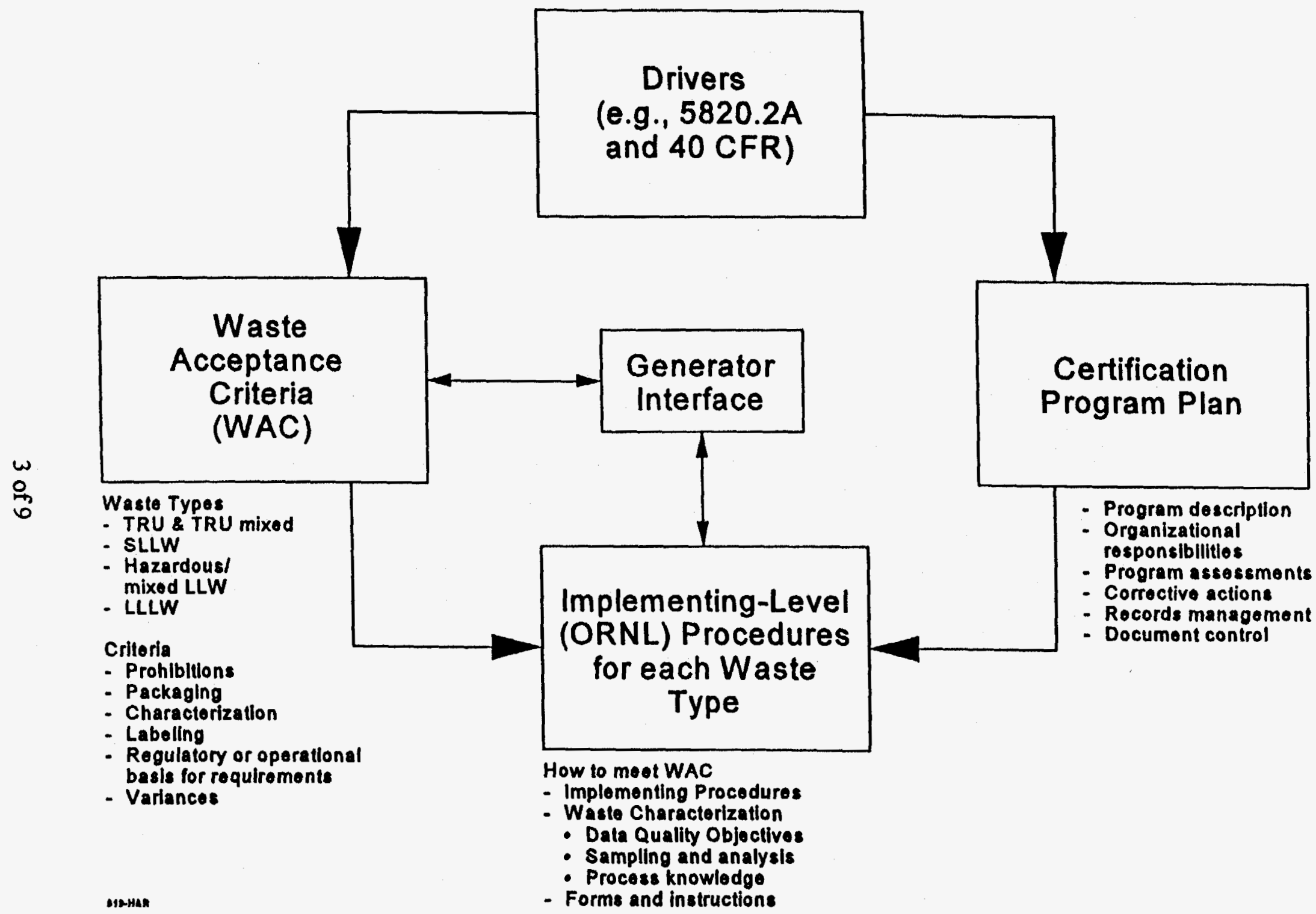

Figure 1. ORNL Waste Certification Program Model 
packaging, arranging transportation of waste, assisting with or managing waste accumulation areas, assisting with pollution prevention, and supporting audits and assessments.

\subsection{CERTIFICATION PROCESS}

Certification of waste is accomplished through the joint efforts of waste generators and Waste Management personnel. The process by which waste is transferred from generators to Waste Management is illustrated in Fig. 2. Before accepting waste at a TSDF, Waste Management provides controls for acceptance. The first point of control is the review of the waste description forms supplied by the generator and verification that applicable WAC requirements have been met. Routine waste inspection of accepted containers will be conducted to verify form information. Some SLLW and TRU will undergo an additional inspection control point at the Waste Examination and Assay Facility (WEAF). This inspection may include nondestructive examination (NDE) to ensure that prohibited waste items are not included in waste packaging; the inspection also verifies certain waste characteristics. TRU waste is subjected to nondestructive assay in addition to NDE. After the final inspection or control point is completed, the waste profile descriptions become the quality records for that particular certified waste package. Certified waste is waste that has been confirmed to comply with receiving facilities' WACs under this certification program.

\section{ORGANIZATIONAL RESPONSIBILTIES}

Figure 3 shows the organizational responsibilities for the waste certification program.

\subsection{ORNL WASTE CERTIFICATION COORDINATOR}

The ORNL Waste Certification Coordinator is responsible for the overall coordination of the program. The Coordinator reports through the Associate Director of the Office of Environment, Safety, and Health. Specific responsibilities include the following:

- preparing and maintaining the waste certification program;

- communicating program changes;

- coordinating and participating in the certification program audits;

- establishing waste certification training requirements;

- validating compliance with program procedures and documents;

- coordinating the surveillance program;

- conducting surveillances; and

- verifying implementation of corrective actions for identified issues. 


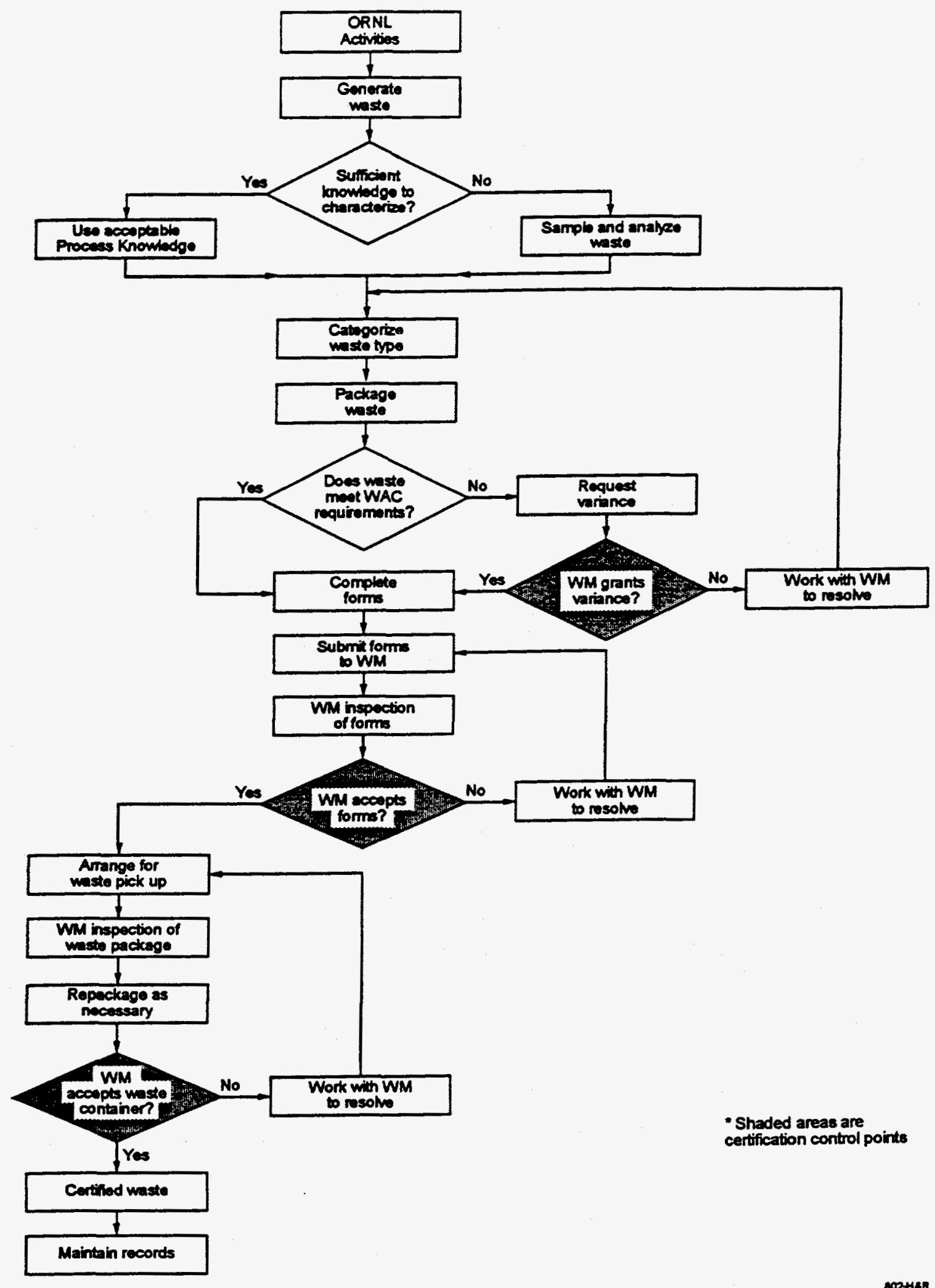

Figure 2. Certification Activities 


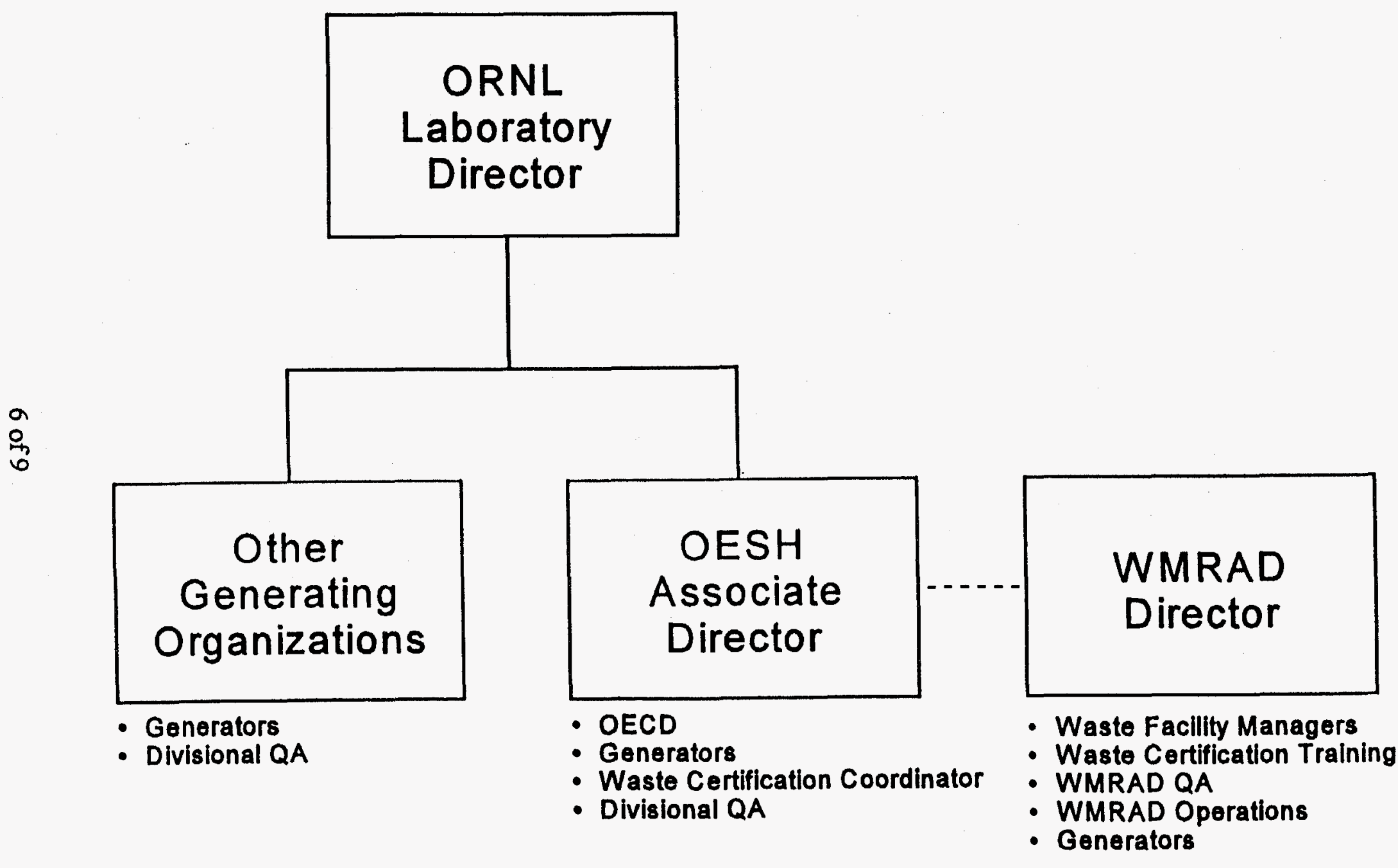




\subsection{WASTE MANAGEMENT ORGANIZATION}

The Waste Management Organization is responsible for the following:

- preparing and maintaining WACs;

- collecting waste from generators;

- verifying compliance with WAC requirements;

- approving variance requests to the WACs;

- operating on-site TSDFs;

- ensuring that off-site WAC requirements are met;

- coordinating and contracting with off-site TSDFs; and

- participating in annual waste certification audits.

The generator interface program is under development. Specific responsibilities for these personnel are expected to be established on a case-by-case basis through the use of a Memorandum of Understanding between the generator and Waste Management. The primary responsibility of the generator interface personnel will be to assist the waste generators in meeting their certification responsibilities (Sec. 4.3). This includes notifying generators of changes to WAC requirements. In addition, generator interface personnel may be asked to provide the following services:

- coordinating waste removal;

- forecasting waste generation;

- managing waste accumulation areas;

- performing routine inspections/walkthroughs; and

- providing assistance in pollution prevention and waste minimization.

\subsection{WASTE GENERATORS}

Waste generators are responsible for the safe management of waste until it is transferred to Waste Management. As part of the certification program, generators have the following responsibilities:

- attending waste certification training as appropriate to their operation;

- properly characterizing, segregating, handling, categorizing, labeling and packaging the waste;

- providing complete, accurate information on waste description forms;

- meeting all WAC requirements for transfer of waste or requesting variance;

- participating in waste certification audits as scheduled; and

- maintaining records of how waste was generated and categorized until waste is accepted by Waste Management. 


\subsection{OFFICE OF ENVIRONMENTAL COMPLIANCE AND DOCUMENTATION}

The Office of Environmental Compliance and Documentation (OECD) will be responsible for the following:

- reviewing WACs;

- coordinating the preparation and revision of waste certification implementing-level procedures;

- participating in an annual certification program audit;

- providing guidance on permitting and regulatory compliance issues; and

- reviewing and approving compliance-oriented variances to WAC requirements.

\subsection{QUALITY ASSURANCE}

Divisional Quality Assurance personnel are responsible for the following:

- scheduling and completing periodic surveillances in their area of responsibility;

- coordinating divisional surveillances through the Waste Certification Coordinator;

- providing surveillance results to the Waste Certification Coordinator and division management for review, evaluation, and distribution; and

- preparing lessons-learned reports and action plans for correction of deficiencies as necessary following existing ORNL procedures.

\section{PROGRAM ASSESSMENTS}

The waste certification program will be validated through an audit of the entire program. An audit will be conducted annually for the four WACs included in this program plan. This audit will be in addition to the regular control-point verifications and periodic surveillances by divisional QA personnel. If program deficiencies are indicated, additional assessment focus will be provided to ensure that those areas demonstrate the expected quality improvement. The audit team will include representatives from OECD, Waste Management, the generating organization(s), Quality Assurance, and other areas as deemed necessary by the ORNL Waste Certification Coordinator.

\section{CORRECTIVE ACTIONS}

Corrective actions will be developed for all deficiencies identified during waste certification program audits or assessments. A corrective action report will be prepared to 
document actions taken. All activities associated with corrective actions will be conducted in accordance with existing ORNL corrective action procedures.

\section{RECORDS MANAGEMENT}

Program documents, which provide evidence of compliance, will be maintained. The primary repository for these documents will be the Waste Management and Remedial Action Division Document Management Center. These records will be held a minimum of five years or as directed by applicable regulations or DOE requirements. At a minimum, records will include the following:

- waste description forms and supporting information;

- final assessment reports;

- final corrective action reports;

- completed surveillance reports;

- WAC variance or exemption approvals;

- WEAF inspection reports;

- waste packaging inspection reports;

- procurement waste packaging specifications; and

- off-site shipping papers.

\subsection{DOCUMENT CONTROL}

Program documents will be controlled as specified in the ORNL Standard Practice Procedure X-AD-9, ORNL Document Control.

When the existing procedures require revisions, and as new program procedures are needed, requests for these additions or revisions will be presented to the ORNL procedure review committee for concurrence and permission to proceed. At least once every five years, all related plans, WACs, and procedures will be reviewed for relevancy and revised as necessary. 